\title{
Comments on Caddo Origins in Northwest Louisiana
}

\author{
Jeffery S. Girard
}

Northwestern State University of Louisiana

Follow this and additional works at: https://scholarworks.sfasu.edu/ita

Part of the American Material Culture Commons, Archaeological Anthropology Commons, Environmental Studies Commons, Other American Studies Commons, Other Arts and Humanities Commons, Other History of Art, Architecture, and Archaeology Commons, and the United States History Commons

Tell us how this article helped you.

This Article is brought to you for free and open access by the Center for Regional Heritage Research at SFA ScholarWorks. It has been accepted for inclusion in Index of Texas Archaeology: Open Access Gray Literature from the Lone Star State by an authorized editor of SFA ScholarWorks. For more information, please contact cdsscholarworks@sfasu.edu. 


\section{Comments on Caddo Origins in Northwest Louisiana}

Creative Commons License

(c) (i) (8)

This work is licensed under a Creative Commons Attribution-NonCommercial 4.0 International License 


\title{
Comments on Caddo Origins in Northwest Louisiana
}

\author{
Jeffrey S. Girard
}

\begin{abstract}
INTRODUCTION
This paper presents some of my thoughts on the issue of Caddo origins from the perspective of the Red River drainage in northwest Louisiana. These ideas were assembled prior to the Caddo discussion group meeting held in December 2008 and have been only slightly modified here. The paper was not given as a formal presentation, but I attempted to introduce the main points during the group discussion.

Development of better chronological controls is crucial for addressing problems of Caddo origins, and I discuss this issue first. Although much has been settled since the early Krieger-Ford discussions, a finer-grained chronology is necessary to answer questions that are now of interest. We remain largely dependent on our understanding of changes in ceramic assemblages and how we can tie these to chronometric scales based primarily on radiocarbon dating.

I next review the cultural taxonomic units that have been used to classify the pre-Caddo archaeological record in the Trans-Mississippi South. Rather than taking the view that one or more of these cultural entities transformed into Caddo culture, I suggest that Caddo origins might be better viewed as the development of social and economic behaviors that linked relatively small-scale social units previously only loosely and sporadically associated. I then discuss the possible importance of the development of ceremonial centers, the appearance of elite mortuary traits, and the circulation of finely engraved ceramic vessels for understanding changes in social and economic integration that took place in the TransMississippi South between approximately A.D. 900 and A.D. 1050. Finally, I offer a list of some basic questions that I feel are important for furthering our understanding of Caddo origins.
\end{abstract}

\section{CHRONOLOGICAL ISSUES}

Early research on the issue of Caddo origins focused on establishing temporal priority to certain culture traits in order to determine their place of origin and direction of diffusion. Alex Krieger, based on his analysis of the George C. Davis site, initially suggested that the Caddo tradition first developed at a time level contemporary with the Middle Woodland period Marksville and Hopewell cultures (Newell and Krieger 1949: 219-224). It followed from this idea that Mississippian traits may have diffused from Mexico, through the Caddo area, and into the Mississippi valley. James Ford's views were different. To Ford, the Caddo area represented a late diffusion of Mississippian traits to the west. He disagreed with Krieger's chronology by arguing that: (1) the Davis site actually shows relatively little ceramic variation and is not likely to represent a long occupation; and (2) Caddo ceramic traits do not occur in the lower Red River region until after the Coles Creek period (Ford 1951:127). In his summary in the Belcher site report, Clarence Webb (1959:207) shortened Krieger's chronology but argued for more time depth than suggested by Ford:

Looking at the entire picture of the lower Mississippi Valley sequence and the Caddoan sequence, it seems reasonable to think that Caddoan beginnings in Alto, Spiro, and Gahagan were approximately coincidental with the introduction in the lower valley of temple mounds, small projectiles and French Fork-Coles Creek Incised-Mazique Incised and Rhinehart Punctated pottery types, whether one calls this Troyville or Coles Creek. Coles Creek was apparently contemporaneous with Gibson aspect, Plaquemine with Bossier and Belcher foci, and Natchez with late Belcher, Mid-Ouachita and Glendora foci. These alignments may be shifted slightly one way or the other at some particular point, but this sequence seems to best fit traits held in common, various suggested movements or influences, and actual trade objects. 
By the early 1960 s, there seems to have been a general consensus that Caddo beginnings were contemporary with the Coles Creek culture in the Lower Mississippi Valley. Radiocarbon dates were sparse, however, and the timing and nature of Coles Creek - Caddo relationships were poorly understood. Phillips' (1970) synthesis clarified some issues, but problems with dating the Baytown and Early Coles Creek periods resulted in continued difficulties for understanding how the earliest Caddo occupations correlated with the Lower Mississippi Valley sequence.

There appears to have been a gradual increase in distinctive Caddo ceramics during the $10^{\text {th }}$ and early $11^{\text {th }}$ centuries A.D. along the Red River in northwest Louisiana and southwest Arkansas. The ceramic characteristics considered "Caddo" that came into use during this time are:

1. decorative bands consisting of multiple, close-spaced horizontal lines, on deep bowls and jars - similar to the later Hardy variety of Coles Creek Incised in the Lower Mississippi Valley; many vessels apparently had unzoned punctations on vessel bodies (Kiam Incised) marking the beginning of the Caddo tradition of treating vessel rims and bodies as distinct design fields (cf. Schambach 1982).

2. carinated bowls with zoned punctated decorations. Contemporary zoned punctated vessels were made in the Lower Mississippi Valley (Avoyelles Punctated), but rarely on carinated bowls.

3. polished vessels with engraved designs, most of which were serving vessels (bowls, carinated bowls, bottles) and may have had special significance beyond their utilitarian functions (see below).

Although these traits differentiate Caddo assemblages from those in the Lower Mississippi Valley and mark the beginnings of a Caddo ceramic tradition, sites dating to the middle $11^{\text {th }}$ century also include, and often are dominated by, vessels similar to Middle Coles Creek phases in the Lower Mississippi Valley, especially the Coles Creek, Greenhouse, and Blakely varieties of Coles Creek Incised; with lesser amounts of French Fork Incised, Beldeau Incised, and Hollyknowe Pinched/Ridged. These Coles Creek ceramics pertain primarily to the Pritchards Landing phase in the lower Ouachita River valley
(Kidder 1990), the Greenhouse phase of the lower Red River (Belmont 1967), and the Balmoral phase in the Tensas River basin (Kidder 1992), all of which date approximately to the A.D. 900 to A.D. 1050 interval (Kidder 1990, 1992; Weinstein et al. 2003). As noted by Schambach (1982), however, ceramic fabrics in the Trans-Mississippi South tend to differ from Coles Creek contexts to the east and there often are subtle design variations.

There is some evidence, however, that distinctively Caddo ceramics date earlier than A.D. 900. The James Pace site (16DS268) in the middle Sabine River drainage, like Mound 3 at Mounds Plantation, has many Coles Creek Incised var. Hardy sherds, as well as a few engraved specimens (Jensen 1968; Story 1990:317-319; Girard 1994). Pace also contains a significant number of sherds with one or two incised lines that appear to relate to Early Coles Creek varieties. Only two radiocarbon dates have been obtained from the site, and these suggest that occupation may have begun there as early as A.D. 700, and then lasted until shortly after A.D. 1000 (Girard 1994). Insufficient work has been done at the Pace site to isolate early and late contexts. No Early Coles Creek types were identified in or beneath Mound 3 at Mounds Plantation, suggesting that occupation of that portion of the site began after A.D. 900. However, Early Coles Creek sherds have been recovered in surface collections and initial occupation of the site likely dates at least as early as the $9^{\text {th }}$ century. However, it is not clear whether or not Caddo types also were in use at that time. Early varieties of Coles Creek Incised were recovered from the deep midden at the Festervan site (16BO327) in Bossier Parish where a radiocarbon date that calibrates in the A.D. 686-878 range was obtained, fitting well with the Lower Mississippi Valley chronology (Girard 1995). No distinctly Caddo materials were present in the lower levels of the midden. Festervan has a Late Caddo period component as well, however, and a few later sherds were mixed in the upper portion of the midden. Thus, current data from northwest Louisiana indicate that, in the A.D. 900 to 1050 interval, early Caddo pottery was mixed in assemblages that also contained substantial amounts of Middle Coles Creek types. The full range of Early Caddo period ceramics was in use by the late $11^{\text {th }}$ century.

From the Crenshaw site in southwest Arkansas, Schambach (1982:152) reported one radiocarbon age from a Crenshaw phase (Late Fourche Maline) context and five from Lost Prairie phase (Early Caddo period) contexts. Estimating the C12/C13 
correction on these ages and calibrating the results indicate that the Crenshaw phase dates prior to A.D. 1050 and the Lost Prairie phase dates in the A.D. 1050 to 1250 range. As at Mounds Plantation, the presence of Early Coles Creek ceramics at Crenshaw suggests that the earliest occupations might be in the A.D. 700 to A.D. 900 range. Troyville types have not been identified, however, perhaps indicating that little or no significant activity took place at Crenshaw or Mounds Plantation prior to that time. No contexts have been reported where distinctively Caddo ceramics are mixed with these Early Coles Creek types.

In eastern Texas, however, radiocarbon dates from the George C. Davis site suggest that Caddo ceramics began to appear by the $9^{\text {th }}$ century A.D. (Story and Valastro 1977; Story 1981, 1990). Story (2000: Figure 3) places the earliest Caddo occupations at the George C. Davis site in the middle $9^{\text {th }}$ century, but the largest number of radiocarbon dates from the village area fall in the A.D. 950 to A.D. 1200 range (Story 1997:96). Perttula (2008) recently reported Caddo-like decorations on Mossy Grove sandy paste ceramics in the Lake Naconiche area (Attoyac Bayou drainage) in eastern Texas. Contexts from the Boyette site (41NA285) appear to date as early as the $7^{\text {th }}$ and $8^{\text {th }}$ centuries A.D.

\section{CULTURAL CONTEXTS}

Although ceramics with decorations similar to Middle Coles Creek types in the Lower Mississippi Valley were abundant in the middle Red River drainage between A.D. 900 and 1050, the meaning of this connection is of considerable dispute. The issue is particularly important as it pertains directly to discussions of the beginnings of the Caddo cultural tradition.

The prevailing view in Louisiana has been based on the ideas of Clarence Webb who saw Caddo origins as resulting from expansion of Coles Creek culture from the Lower Mississippi Valley, and contact with Mesoamerican groups. Webb argued that Coles Creek hamlets and villages were scattered in the Red River floodplain and along upland streams. The Coles Creek groups constructed a small number of civic-ceremonial centers including Mounds Plantation, the Gahagan site in Red River Parish, and the Crenshaw site in southwestern Arkansas (Webb and Gregory 1986:3-4). Webb left open the question of whether Caddo culture is a locally transformed
Coles Creek manifestation, or whether an influx of new peoples is represented. He seemed to favor the former (Webb and McKinney 1975:120-121) and followed Krieger's early arguments suggesting that Mesoamerican influences are linked to early Caddo developments, particularly certain ceramic traits (carinated bowl and bottle forms, polished/smudged surfaces, engraving/excising, curvilinear motifs) and mortuary practices (multiple burials of elites in deep, shaft graves).

Based on information from southwestern Arkansas, a different point of view has been expressed by Frank Schambach (1982, 2002). Schambach argues that long-term local cultural continuity is represented in the Red River drainage with only minimal influences from the Lower Mississippi Valley. He classifies all pre-Caddo developments in the woodlands west of the Lower Mississippi Valley (the Trans-Mississippi South) within the Fourche Maline culture concept. Fourche Maline sites are identified by the presence of distinctive, thick-walled ceramic jars, usually flowerpot or beaker-shaped. The jars were tempered with grog, grit, and sometimes crushed bone. Most abundant and widespread is the grog-tempered type Williams Plain. Other traits include contracting stem (Gary) dart points, double-bitted axes, boatstones, platform pipes, and abundant ground stone tools (Schambach 2002:91-3). Fourche Maline houses have proven difficult to detect-postholes, wall trenches, and other evidence of structural remains have not been identified. In southwestern Arkansas, floodplain settlement on natural levees in the then active Red River meander belt and along crevasse displays is evident (Kelley and Coxe 1998:204). Small villages, 2-10 acres in size, may be represented (Schambach and Early 1982:72). Similar sites have been recorded in northwest Louisiana, north of the Shreveport area. The Fourche Maline subsistence economy is not well understood. Schambach (2002:103-108) discusses the possibility that cultivation of starch/ oily seed crops took place. Abundant grinding stones and double-bitted axes might reflect gardening and seed processing. However, no plant food remains have been recovered.

Schambach sees Fourche Maline culture as an adaptation to the environments of the TransMississippi South. Unfortunately, possible differences between Woodland period economies of the Trans-Mississippi South and those in the Lower Mississippi Valley have never been explored in more than a cursory manner. Given the differences in the 
landscape, an overall greater focus on bottomland, riverine resources in the Lower Mississippi Valley (cf. Kidder and Fritz 1993:294), in contrast with a focus on upland resource exploitation in the TransMississippi South, might be expected. Several major traits attributed to Fourche Maline culture by Schambach may be linked to subsistence practicesspecifically, large thick-walled vessels, black-earth middens, and abundant grinding equipment. It is possible that these traits relate to an emphasis on nut processing, particularly hickory nuts, which are abundant in the oak-hickory-pine vegetation regime within which the sites appear to cluster. It also is possible that the Fourche Maline inhabitants adopted oily/starchy seed crop horticulture and that double-bitted axes are cultivating tools, as suggested by Schambach (2002:104-105).

The Fourche Maline economy may have contrasted with subsistence economies in the Piney Woods region to the south, and with those in the Lower Mississippi Valley where bottomland, riverine resources were of primary subsistence importance at least since the Middle Archaic period (e.g., Jackson and Scott 2001; Gibson 2000; Kidder and Fritz 1993). The Woodland period archaeological record in the segment of the Red River floodplain between the mouth of Loggy Bayou and the Natchitoches area is poorly known. The hills adjoining the floodplain in this region are covered by the Piney Woods where few Woodland period contexts have been identified. Fourche Maline black-earth middens with Williams Plain pottery do not seem to occur here. Although it is possible that the paucity of sites is due to poor sampling, there also may have been no distinct local population that inhabited the area. Rather, sporadic use by groups from the northwest and southeast might be represented.

In the Natchitoches area, two major tributaries on the east side of the Red River floodplain, Black Lake Bayou and Saline Bayou, converge to produce a swampy, lowland environment, major portions of which are now continually inundated by a series of lakes (Black Lake, Clear Lake, Saline Lake, and Chee Chee Bay). In many respects, this area mimics environments in the Lower Mississippi Valley. The area also has been long noted for archaeological similarities to the Lower Mississippi Valley for periods pre-dating about A.D. 1000 . Best known are sites of the Fredericks phase (Fredericks and Montrose sites) with ceramics similar to Troyville culture sites to the east (Girard 2000), and the slightly later Lemoine phase (Black Lake Bayou, Lemoine, Edwards, and MacNeely sites) with ceramics similar to Early Coles Creek sites (Girard 2001). Similar sites are present to the south into the Red River floodplain between the present cities of Natchitoches and $\mathrm{Al}$ exandria, where three major channels were active in late prehistoric and historic times.

Schambach argues that Fourche Maline is the single cultural antecedent to Caddo culture. The transition was linked to initial participation of Late Fourche Maline peoples in the developing Mississippian interaction sphere. Strongest connections were to the north, with ornamental trade goods and a distinctive mortuary program resulting from contacts with Cahokia (Schambach 2002:112). In contrast to Webb, Schambach (1982:190) sees little evidence that Coles Creek peoples of the lower Red and Ouachita River drainages influenced developments farther upstream on the Red River at this time.

Like Schambach, Story (1990:323) argued that migration hypotheses for Caddo origins are unsupported by archaeological evidence. However, like Webb, she suggested that influences from the Lower Mississippi Valley are likely to have played an important role. Story argued that several different cultural traditions, probably with roots deep in the Woodland period, are direct ancestors to the Caddos. One of these, the Mossy Grove culture, is distinguished by distinctive sandy paste ceramics, and existed in the Neches and Angelina River drainages in East Texas. Perttula and Nelson (2004) proposed that a culture designated Mill Creek was situated in the upper Sabine River drainage, portions of the Big Cypress Creek drainage, and upper Angelina River basin, between the Mossy Grove and Fourche Maline peoples.

Differences in interpretations regarding Caddo cultural antecedents relate, in part, to the lack of distinct ceramic stylistic criteria on which to formulate taxonomies. It is possible that, prior to about A.D. 900 , the fluid nature of social and territorial boundaries minimized group stylistic behavior. Local ceramic types are defined on the basis of general technological traits, not on the basis of decorative styles which, when present in the Trans-Mississippi South, mimic those in the Lower Mississippi Valley. Archaeological "phases" with distinct spatial boundaries are difficult to define under these circumstances. 


\section{SOCIAL AND ECONOMIC INTEGRATION}

The phenomena that archaeologists have considered to represent the beginnings of Caddo culture in northwest Louisiana clearly relate to broader patterns of social and economic integration that took place in the Trans-Mississippi South after about A.D. 900, and are linked to early "Mississippian" developments in general in the Southeast. Throughout most of the Trans-Mississippi South, Late Woodland social and economic relationships between local groups probably were poorly defined and ephemeral. North of the Fredericks site in the Natchitoches area, no population centers or ceremonial areas are known that would suggest the existence of an over-arching political structure or ideology that bound groups together. If archaeological constructs such as Fourche Maline, Mossy Grove, or Mill Creek had cultural reality in the past, they were entities only in the most generic sense. These "cultures" cover vast expanses of the landscape and are defined on the basis of general technological, rather than stylistic, criteria. As noted above, such large-scale, generic cultural constructs might be useful as analytic units for addressing questions concerning variation in widespread ecological adaptations. However, understanding Caddo beginnings might be better viewed as the integration of multiple, relatively autonomous social units, rather than as the transformation, and subsequent diffusion, of existing large-scale "cultural" entities.

Although the archaeological record for the $8^{\text {th }}$ through $10^{\text {th }}$ centuries is poorly known, it does seem clear that by the early $11^{\text {th }}$ century, relatively highly integrated social units had formed and persisted in areas where smaller, more autonomous groups once existed. From a functional perspective, communities linked by close social and economic ties may have had advantages over smaller, isolated communities because these bonds: (1) minimized social barriers for exchange of resources from varying portions of the landscape; (2) facilitated intensification of food production in the form of agriculture, and consequent generation of surpluses and re-distribution in times of need; (3) enabled aggression against less integrated neighbors for resources or labor; and (4) provided protection from other groups undergoing similar changes. As some groups adopted this course, others were compelled to do likewise or be eliminated as separate systems of organization (or at least their residues would not be recognized as distinct entities in the archaeological record).
If integration of multiple communities is represented by the presence of ceremonial centers, in portions of the Lower Mississippi Valley, and to a lesser degree up the Red River as far as the Natchitoches area, this phenomenon had been ongoing during the Late Woodland period, and perhaps earlier. The Fredericks site in Natchitoches Parish is the northernmost example of such a center during the Late Woodland period (Girard 2000). However, most of the Trans-Mississippi South was isolated from these trends until the period between approximately A.D. 900 and A.D. 1050 when the first ceremonial centers (multiple mounds surrounding plazas) appeared in the Red River floodplain. Development of these centers was accompanied by (1) the beginnings of a distinctive mound mortuary program; (2) the first evidence of dispersed floodplain villages; and (3) dramatic changes in ceramic vessel forms and decorations, including the initial presence of fine engraved pottery, a form of decoration that did not exist in the Lower Mississippi Valley or elsewhere in the Southeast at that time. A major research issue for the region is establishing the chronological order that these traits were developed or adopted. With present chronological resolution, all appear roughly simultaneously and, thus, seem to be closely linked.

\section{THE ESTABLISHMENT AND DEVELOPMENT OF CEREMONIAL CENTERS}

Inter-community integration is visible in the archaeological record by the presence of ceremonial centers. Several recent studies in the Southeast attempt to identify and understand the significance of the ceremonies likely to have been conducted at these centers, stressing the role of feasting in the establishment of regional polities and social hierarchies (e.g., Knight 1986; Blitz 1993; Jackson and Scott 1995; Kelly 1997; Pauketat et al. 2002). In these studies, ethnographic and historic information is used to demonstrate that connections between communities are created when some groups host feasts that cross-cut existing social barriers (such as kinship ties) and institute new links between formerly unaffiliated or even hostile groups. Means of communication and cooperation often are established whereby decisions beneficial to security and prosperity are made on regional, rather than local, scales. Dietler and Herbich (2001:243) note that feasts may involve the mobilization of 
labor, including land clearing and field preparation. Such "work feasts" enabled hosts to produce food surpluses both to sponsor additional feasts and to re-distribute food in times of need.

Kidder (1998a:132-133) argued that a major difference existed between Coles Creek culture settlements in the Lower Mississippi Valley and Early Caddo settlements along the Red River. Early Coles Creek ceremonial centers consisting of two or three mounds arranged around a central plaza were present by the $9^{\text {th }}$ century. Such sites became increasingly numerous through time, eventually forming a social landscape consisting of multiple small scale "petty chiefdoms" not dominated by any single center (Kidder 1992:154, 1998b:140). In contrast to the Lower Mississippi Valley, Kidder (1998a:133) sees evidence that the Early Caddo landscape consisted of a few paramount centers, roughly evenly spaced across the region, without smaller, secondary centers. Ceremonial centers in both areas were used both for public rituals and as mortuary facilities for elites. Elite burials at the Caddo centers, however, exhibit greater evidence of concentration of wealth and power in the hands of a limited number of individuals, and Kidder (1998a:133) suggests the existence of "a vertically ranked society with territorially distinct authority over large areas."

Unfortunately, few Early Caddo period ceremonial centers in the Red River drainage are actually known. Only the Mounds Plantation site, located north of Shreveport, is documented in northwest Louisiana. The Crenshaw and Bowman sites in Southwest Arkansas also were major Early Caddo ceremonial centers, but none of the Caddo sites are particularly large compared to their Coles Creek contemporaries. Although the dynamic nature of the Red River undoubtedly has destroyed some mounds (Schambach 1982:11), relative to the Lower Mississippi Valley, mound construction appears to have been an infrequent activity along the Red River prior to A.D. 1200 . The number of ceremonial centers is so few that it makes little sense to interpret their spacing except to note that they are at considerable distances from one another. It seems more reasonable to view the centers as disconnected attempts at local social integration, rather than as representing the sudden emergence of a hierarchically structured political entity in control of a vast region.

\section{ELITE MORTUARY PATTERNS}

Despite having a complex social hierarchy as evidenced by the settlement patterns, late Baytown and early Coles Creek community or regional leaders in the Lower Mississippi Valley were not distinguished through special mortuary treatments. Mass burials on platforms or in shallow pits later covered by earth to form low mounds were present at sites such as Greenhouse (16AV2), Gold Mine (16RI13), Mt. Nebo (16MA18), and Old Creek (16LA77) (Ford 1951; Jones 1979; McGimsey 2004; Giardino 1984; Gibson 1984). The Gold Mine site (16RI13), which has radiocarbon dates in the A.D. $775-875$ interval, probably was used by multiple small communities. As is the case with the other burial sites, numerous individuals were buried together with no evidence of status differentiation (McGimsey 2004:214). Individuals do not appear to have been carefully placed and many bones are missing. The lack of highly decorated ceramic vessels or goods of exotic stone, marine shell, or copper in burials continued in the subsequent Coles Creek periods, and this pattern contrasts markedly with the $11^{\text {th }}$ century shaft tombs at Early Caddo period sites such as Crenshaw, Mounds Plantation, Gahagan, and George C. Davis.

Mound 5, the major mortuary facility at the Mounds Plantation site, was constructed in two stages. Seven burial pits were dug prior to the final capping of the primary mound. Grave goods were limited to arrow points. Six burial pits were made during construction of the secondary mound. Holly and Hickory Fine Engraved vessels, along with numerous elaborate burial goods, were placed in four of these pits. Webb saw changes in Mound 5 burial traits as evidence of a transition from the earliest occupation of the site by Coles Creek peoples, to the later Early Caddo occupation. Because the burials made from levels above the primary mound did not intrude on the earlier burials, and multiple individuals laid out in rows were present in both primary and secondary mound burial pits, Webb argued that: "There is evidence in Mounds 3 and 5 of a progressive and rapid shift from Coles Creek to Caddoan (Alto) culture with little evidence of time lag and no indication of desertion and reoccupation" (Webb and McKinney 1975:120). Unfortunately there are no radiocarbon dates from the early Mound 5 burials, and the absence of ceramic vessels precludes comparisons with other areas. 
Perhaps the earliest burials at a mound center in the Trans-Mississippi South are present at the Crenshaw site in southwest Arkansas. In Mound C at least four large clusters of human burials were made on top of a low earthen platform that subsequently was buried by mound deposits. As in the Lower Mississippi Valley sites, numerous individuals were placed in mass graves. However, in contrast to the Lower Mississippi Valley pattern, individuals were placed in neat rows and multiple burials goods (Coles Creek Incised ceramic vessels, ceramic pipes, arrow points, bone awls) were included in the graves (Durham and Davis 1975). Although these contexts have not been radiocarbon dated, the Early Coles Creek pottery strongly suggests that the burials date prior to A.D. 1000. The linear mass burials at Crenshaw resemble those in Mound 72 at Cahokia, but may pre-date the Cahokia burials by two centuries or more.

The later burials in Mound $\mathrm{C}$ at Crenshaw were sunk deeply into the mound fill that capped the low platform. These graves contain fewer individuals, Early Caddo period ceramic vessels and other grave goods, and likely date to the $11^{\text {th }}$ century or later based on dates from similar burials at Mounds Plantation, Gahagan, and George C. Davis. Better chronological control and more detailed comparisons of mortuary patterns at ceremonial centers between the Fourche Maline-Early Caddo sequence in the Trans-Mississippi South and the Early to Middle Coles Creek sequence in the Lower Mississippi Valley would greatly enhance our understanding of Caddo origins.

\section{FINE WARE CERAMICS}

The widespread distribution of engraved ceramics by the Early Caddo period might be a consequence of regional interaction between diverse social groups that were in the process of forming sedentary communities with incipient social hierarchies. The interaction consisted of exchange or emulation of prestige goods displayed in community social contexts, most likely rituals involving feasting. It is possible that highly polished, finely engraved ceramic bowls and bottles were among such prestige items in the Early Caddo period. Two basic forms of decoration are represented-vessels with simple lines around vessel rims (Hickory Engraved), and highly elaborate rectilinear and curvilinear patterns, often with excised zones and pigment rubbed into both lines and zones (Holly Fine Engraved and Spiro Engraved). Vessels tend to have thin vessel walls, fine paste, and designs are exceptionally finely executed. These traits suggest manufacture by a limited number of highly skilled artisans.

In northwest Louisiana during the Early Caddo period, finely engraved sherds appear only in small amounts in village debris. However, they are the exclusive vessel forms placed in the mound burials at both the Mounds Plantation and Gahagan sites. Such vessels may have been displayed in rituals and were sources of community pride, but access and use probably were limited to specific groups within communities. The dominance of serving vessels (bowls, bottles) suggests that they were displayed in ceremonial contexts, probably involving feasts or ritual consumption of food.

Importantly, regardless of where they were manufactured, similar attributes (paste, vessel forms, and general decorative patterns) occur on Early Caddo period engraved vessels throughout the Caddo area as represented by the types Hickory Engraved, Holly Fine Engraved, and Spiro Engraved. Apparently these vessels served as accoutrements of wealth, power, and status. They may have been involved in exchanges between emerging elites within the Caddo area, as well as outlying areas, particularly Cahokia and the American Bottom region during the late $11^{\text {th }}$ and early $12^{\text {th }}$ centuries. The engraved pottery seems to signify emerging Caddo culture as distinct from cultures in the Lower Mississippi Valley. Although it is unlikely that the Caddo area was unified in any social or political sense during the Early Caddo period (or anytime thereafter prior to the middle $19^{\text {th }}$ century, see Story 1978 ), a widespread sense of singular cultural or perhaps even ethnic identity may have begun to materialize.

The context of production for early engraved pottery is not known. If the ceramics were produced at a single location and traded to outlying communities, one possible center for production is the George C. Davis site located along the Neches River in East Texas. Holly Fine Engraved was the most numerous decorated type among the estimated 1101 vessels represented in the materials recovered from the Mound A excavations. No collections from northwest Louisiana even remotely approach the quantities represented at Davis. However, no contexts have been excavated that are comparable to Mound A - an "inner precinct" area (Story 1997) possibly confined to elite habitation and ritual. Polished and engraved pottery has been recovered in the Huastecan area along the Gulf Coast of Mexico (Newell and Krieger 1949:224-232; Webb and Gregory 
1986:5), and it is possible that ceramics from this distant region provided the initial inspiration for the Caddo pottery.

Although initially difficult to produce and acquire, by A.D. 1200 in northwest Louisiana engraved pottery appears to have become part of standard household ceramic assemblages. However, the elaborate patterns of Holly Fine Engraved dropped out of use and were replaced by simpler patterns often with hatched or cross-hatched bands or zones (Maddox Banded Engraved, Glassell Engraved, Hempstead Engraved). Engraved pottery with relatively crudely executed, hatched elements began to appear in village contexts during the Early Caddo period (prior to A.D. 1200). These often thick and unpolished vessels likely represent local attempts to emulate the fine wares. General skill levels improved by the Middle Caddo period, and engraved vessels of varying quality apparently were part of every household. Finer examples may have continued to be sources of pride and status. At the Davis site in East Texas, Krieger noted that, through time, execution of design elements on engraved vessels became sloppier and paste appeared to become coarser (Newell and Krieger 1949:83-84). Localization of production of engraved ceramics was a phenomenon that appears to have taken place throughout the Caddo area - a proliferation of types and regional variation is widely recognized after about A.D. 1200 .

\section{RESEARCH QUESTIONS}

The topic of Caddo origins obviously is very complex and can be approached from a variety of theoretical perspectives requiring emphases on differing aspects of the archaeological record. Some basic questions that I regard as important include:

1 Is there a consensus on which archaeological traits are diagnostic of Caddo culture? Do these traits appear gradually through time, or relatively suddenly as a unit?

2 Is there a "center" of Caddo development with subsequent diffusion into surrounding areas, or do Caddo traits emerge from multiple areas as a result of social interactions?

3 Was the initial development of Caddo culture dependent upon, or was it stimulated by, contemporary developments in the Southeast and Mesoamerica?
4 How important are changes in ecological adaptations, particularly subsistence practices, for understanding Caddo origins?

5 Does the appearance of ceremonial centers and elite mortuary ceremonialism in the archaeological record reflect the initial appearance of social hierarchies in the Trans-Mississippi South? Did the region become divided into multiple Caddo "chiefdoms" by A.D. 1200 ?

6 Finally, should we regard the problem of Caddo origins as an example of "ethnogenesis" as developed in anthropological studies?

\section{REFERENCES CITED}

Belmont, John

1967 The Cultural Sequence at the Greenhouse Site, Louisiana. Southeastern Archaeological Conference Bulletin 6:27-34.

Blitz, John

1993 Big Pots for Big Shots: Feasting and Storage in a Mississippian Community. American Antiquity 58(1):80-96

Dietler, Michael and Ingrid Herbich

2001 Feasts and Labor Mobilization: Dissecting a Fundamental Economic Practice. In Feasts, Archaeological and Ethnographic Perspectives on Food, Politics, and Power, edited by Michael Dietler and Brian Hayden, pp. 240-264. Smithsonian Institution Press, Washington, D.C.

Durham, James H. and Michael Davis

1975 Report on Burials Found at Crenshaw Mound "C", Miller County, Arkansas. Bulletin of the Oklahoma Anthropological Society 23:1-90.

Ford, James A.

1951 Greenhouse: A Troyville-Coles Creek Period Site in Avoyelles Parish, Louisiana. Anthropological Papers No. 44(1). American Museum of Natural History, New York.

Giardino, Marcus

1984 Temporal Frameworks: Archaeological Components and Burial Styles: The Human Osteology of the Mt. Nebo Site in North Louisiana. Louisiana Archaeology 9:99-126.

Gibson, Jon L.

1984 Old Creek, A Troyville Period Ossuary in LaSalle Parish, Louisiana: Reflections After a Quarter Century. Louisiana Archaeology 9:127-204. 
2000 The Ancient Mounds of Poverty Point, Place of Rings. University Press of Florida, Gainesville.

Girard, Jeffrey S.

1994 Investigations at the James Pace Site (16DS268), DeSoto Parish, Louisiana. Caddoan Archeology Newsletter V(1):8-16.

1995 Regional Archaeology Program, Management Unit 1: Sixth Annual Report. Report on file at the Louisiana Division of Archaeology, Department of Culture, Recreation, and Tourism, Baton Rouge.

2000 Excavations at the Fredericks Site, Natchitoches Parish, Louisiana. Louisiana Archaeology 24:1-106.

2001 Regional Archaeology Program, Management Unit 1: Twelfth Annual Report. Report on file at the Louisiana Division of Archaeology, Department of Culture, Recreation, and Tourism, Baton Rouge.

Jackson, H. Edwin and Susan L. Scott

1995 The Faunal Record of the Southeastern Elite: The Implications of Economy, Social Relations, and Ideology. Southeastern Archaeology 14(2):103-119.

2001 Archaic Faunal Utilization in the Louisiana Bottomlands. Southeastern Archaeology 20(2):187-196.

Jensen, Hal E.

1968 Archaeological Investigations in the Toledo Bend Reservoir: 1966-1967. Archaeology Salvage Project, Southern Methodist University, Dallas.

Jones, Reca

1979 Human Effigy Vessels from Gold Mine Plantation. Louisiana Archaeology 4:117-121.

Kelley David B. and Carey L. Coxe

1998 Cultural Resources Survey of Levee Rehabilitation/ Restoration Areas Along the Red River Between Fulton, Arkansas and the Louisiana State Line: Items 4, 5, and 9. Report prepared for U.S. Army Corps of Engineers, Vicksburg District. Coastal Environments, Inc., Baton Rouge.

Kelly, Lucretia S.

1997 Patterns of Faunal Exploitation at Cahokia. In $\mathrm{Ca}$ hokia, Domination and Ideology in the Mississippian World, edited by Timothy R. Pauketat and Thomas E. Emerson, pp. 69-88. University of Nebraska Press, Lincoln.

Kidder, Tristram R.

1990 Ceramic Chronology and Culture History of the Southern Ouachita River Basin: Coles Creek to the Early Historic Period. Midcontinental Journal of Archaeology 15(1):51-81.

1992 Coles Creek Period Social Organization and Evolution in Northeast Louisiana. In Lords of the Southeast: Social Inequality and the Native Elites of Southeastern North America, edited by Alex W. Barker and Timothy R. Pauketat, pp.
145-162. Archeological Papers of the American Anthropological Association No. 3.

1998a Rethinking Caddoan-Lower Mississippi Valley Interaction. In The Native History of the Caddo: Their Place in Southeastern Archeology and Ethnohistory, edited by Timothy K. Perttula and James E. Bruseth, pp. 129-143. StudiesinArcheology 30. Texas Archeological Research Laboratory, The University of Texas at Austin.

1998b Mississippi Period Mound Groups and Communities in the Lower Mississippi Valley. In Mississippian Towns and Sacred Spaces, edited by R. Barry Lewis and Charles Stout, pp. 123-150. The University of Alabama Press, Tuscaloosa.

Kidder, Tristram R., and Gayle J. Fritz

1993 Subsistence and Social Change in the Lower Mississippi Valley: The Reno Brake and Osceola Sites, Louisiana. Journal of Field Archaeology 20:281-297.

Knight, Vernon James, Jr.

1986 The Institutional Organization of Mississippian Religion. American Antiquity 51:675-687.

McGimsey, Chip

2004 The Gold Mine Site (16RI13): An AD 825 Ossuary in Northeast Louisiana. Regional Archaeology Program, Management Unit III, 2003/2004 Annual Report. Report on file at the Louisiana Division of Archaeology, Baton Rouge.

Newell, H. Perry and Alex D. Krieger

1949 The George C. Davis Site, Cherokee County, Texas. Memoirs No. 5. Society for American Archaeology, Menasha, Wisconsin.

Pauketat, Timothy R., Lucretia S. Kelly, Gayle J. Fritz, Neal H. Lopinot, Scott Elias, and Eve Hargrave

2002 The Residues of Feasting and Public Ritual at Early Cahokia. American Antiquity 67(2):257-279.

Perttula, Timothy K. (editor)

2008 Lake Naconiche Archeology, Nacogdoches County, Texas: Results of the Data Recovery Excavations at Five Prehistoric Archeological Sites. 2 Vols. Report of Investigations No. 60. Archeological \& Environmental Consultants, LLC, Austin.

Perttula, Timothy K. and Bo Nelson

2004 Woodland and Caddo Archeology at the Broadway or Kanduts'ah Kuhnihdahahdisa' Site (41SM273) on the City of Tyler-Lake Palestine WTP Project, Smith County, Texas. Report of Investigations No. 50. Archeological \& Environmental Consultants, LLC, Austin.

Phillips, Philip

1970 Archaeological Survey in the Lower Yazoo Basin, Mississippi, 1949-1955. Papers of the Peabody Museum, Harvard University, Vol. 60. Peabody Museum of Archaeology and Ethnology, Harvard University, Cambridge. 
Schambach, Frank F.

1982 An Outline of Fourche Maline Culture in Southwest Arkansas. In Arkansas Archeology in Review, edited by Neal L. Trubowitz and Marvin D. Jeter, pp. 132197. Research Series No. 15. Arkansas Archeological Survey, Fayetteville.

2002 Fourche Maline: A Woodland Period Culture of the Trans-Mississippi South. In The Woodland Southeast, edited by David G. Anderson and Robert C. Mainfort, Jr., pp. 91-112. The University of Alabama Press, Tuscaloosa.

Schambach, Frank F. and Ann M. Early

1982 Southwest Arkansas. In A State Plan for the Conservation of Archeological Resources in Arkansas, edited by Hester A. Davis, pp. SW1-SW149. Research Series 21. Arkansas Archeological Survey, Fayetteville.

Story, Dee Ann

1978 Some Comments on Anthropological Studies Concerning the Caddo. In Texas Archeology, Essays Honoring R. King Harris, edited by Kurt D. House, pp. 46-68. Southern Methodist University Press, Dallas.

1981 An Overview of the Archeology of East Texas. Plains Anthropologist 26(92):139-156.

1990 Cultural History of the Native Americans. In The Archeology and Bioarcheology of the Gulf Coastal Plain: Volume 1, pp. 163-366, by Dee Ann Story, Janice A. Guy, Martha D. Freeman, Barbara A. Burnett, Jerome C. Rose, D. Gentry Steele, Ben W. Olive, and Karl J. Reinhard. Research Series No. 38. Arkansas Archeological Survey, Fayetteville.
1997 1968-1970 Investigations at the George C. Davis Site, Cherokee County, Texas. Bulletin of the Texas Archeological Society 68:1-113.

2000 Introduction. In The George C. Davis Site, Cherokee County, Texas, by H. Perry Newell and Alex D. Krieger, pp. 1-31, $2^{\text {nd }}$ Edition. Society for American Archaeology, Washington, D.C.

Story, Dee Ann, and Sam Valastro, Jr.

1977 Radiocarbon Dating and the George C. Davis Site, Texas. Journal of Field Archaeology 4(1):63-89.

Webb, Clarence $\mathrm{H}$.

1959 The Belcher Mound: A Stratified Caddoan Site in Caddo Parish, Louisiana. Memoirs No. 16. Society for American Archaeology, Salt Lake City.

Webb, Clarence H. and Hiram F. Gregory

1986 The Caddo Indians of Louisiana, Second Edition. Department of Culture, Recreation and Tourism, Louisiana Archaeological Survey and Antiquities Commission, Anthropological Study No. 2, Baton Rouge.

Webb, Clarence H., and Ralph McKinney

1975 Mounds Plantation (16CD12), Caddo Parish, Louisiana. Louisiana Archaeology 2:39-127.

Weinstein, Richard A., David B. Kelley, and Joe W. Saunders

2003 Introduction. In The Louisiana and Arkansas Expeditions of Clarence Bloomfield Moore, edited by Richard A. Weinstein, David B. Kelley, and Joe W. Saunders, pp. 1-213. The University of Alabama Press, Tuscaloosa. 